\title{
DESAIN SISTEM INFORMASI PENJUALAN PRODUK ELEKTRONIK MENGGUNAKAN KONSEP E-COMMERCE PADA CV. INDONESIA ELEKTRONIK
}

\author{
Aris $^{1}$ \\ Lilis Wulandari ${ }^{2}$ \\ Rizki Regina Ulfauziah ${ }^{3}$ \\ ${ }^{123}$ Perguruan Tinggi Raharja \\ 1,2,3Jl.Jendral Sudirman No.40,modern,Tangerang,021-5529692 \\ Email : aris@raharja.info,liliswulandari@raharja.info,_Rizkiregina@raharja.info
}

\begin{abstract}
ABSTRAK
Media informasi merupakan sarana penting dalam penyampaian informasi dalam berbagai ruang lingkup kegiatan. Semakin berkembangnya media dalam penyampaian informasi maka semakin cepat dan akuratnya informasi yang diterima dan menjadi lebih baik pemahaman dalam sebuah informasi. Kesalahan dalam memahami sebuah informasi akan banyak menyababkan banyak salah penafsiran, sehingga informasi tersebut tidak dapat menjadi landasan dalam mengambil sebuah tindakan atau sebuah keputusan. Pada CV.Indonesia Elektronik dibutuhkan suatu perancangan sistem yang dapat memudahkan dalam memberikan suatu informasi. Karena masih terbatasnya sistem komputerisasi yang digunakan pada CV.Indonesia Elektronik tersebut. Dalam pendataan penjualan yang dilakukan oleh CV.Indonesia Elektronik telah menggunakan komputer namun masih menggunakan aplikasi Microsoft Word, dan Microsoft Excel akan tetapi penggunaan aplikasi tersebut belum dilakukan secara optimal. Penulisan ini menggunakan metode analisa berorientasi objek dengan tujuan melakukan perancangan sistem yang berjalan pada CV.Indonesia Elektronik. Untuk itu di buat sebuah website yang memiliki tampilan menarik serta menu dan aplikasi yang mudah dimengerti baik oleh konsumen.Untuk membuat katalog produk elektronik secara online yang memiliki informasi lengkap didalamnya dan dapat dimanfaatkan sebagai bahan referensi oleh customer dalam pemesanan produk yang diinginkan. Dan Untuk memudahkan konsumen dalam mencari informasi mengenai toko elektronik online serta memungkinkan pihak perusahaan melakukan brand building untuk produknya secara lebih cepat dan luas. Dengan Metode perancangan Framework e-Commerce yaitu B2B dan B2C Business-tobusiness-to-consumer (B2B2C) dan pengembangan aplikasi sistem yang diusulkan menggunakan metode perancangan Unified Modelling Language (UML) dengan menggunakan alat bantu (tools) berupa Visual Paradigm for 6.4 Enterprise Edition, untuk pembuatan sistem ini menggunakan Macromedia Dreamweaver sebagai penulisan listing program php dan mysql sebagai databasenya, Hasil dari penulisan ini berupa rancangan sistem berbasis web ini yang dapat memberikan manfaat yang positif bagi CV.Indonesia Elektronik. CV.Indonesia Elektronik bisa bersaing dengan perusahaan elektronik lainya yang bergerak pada penjualan online.
\end{abstract}

Kata Kunci : Sistem Informasi, E-Commerce, Komputerisasi

Vol.2 No.1 - Februari 2016 


\begin{abstract}
Media information is an important tool in disseminating information in various spheres. The continued development of the media in disseminating information, the quicker and more accurate information received and the better understanding in an information.Errors in understanding a lot of information will lead to a lot of misinterpretation, so that the information can not form the basis for taking an action or a decision.In CV.Indonesia Electronics needed a design system that can facilitate in providing information. Because of the limited computerized systems used in the Electronic CV.Indonesia.In the collection of sales made by CV.Indonesia Electronics has used a computer but still using Microsoft Word, and Microsoft Excel but the use of these applications is not optimal.This study, using object-oriented analysis with the aim of designing a system that runs on CV.Indonesia Electronics.For that created a website that has an interesting display and menu and applications are easily understood by the consumer.To make an online catalog of electronic products that have full information therein and can be used as reference material by the customer in ordering the desired product.And to enable consumers to search for information about an online electronics store and allows employers to do brand building for its products more rapidly and widely. With a design method Framework e-Commerce, namely B2B and B2C Business-to-businessto-consumer (B2B2C) and application development proposed system uses design methods Unified Modelling Language (UML) using tools (tools) such as Visual Paradigm for 6.4 Enterprise Edition, for making this system using Macromedia Dreamweaver as a writing program listings php and mysql as the database, results of this paper in the form of a web-based system design that can provide positive benefits for CV.Indonesia Electronics. Electronic CV.Indonesia can compete with other electronic companies engaged in online sales.
\end{abstract}

Keywords: Information Systems, E-Commerce, Computerized

\title{
PENDAHULUAN
}

Dalam perkembangan teknologi dan informasi saat ini diperlukan kecepatan dan keakuratan dalam mendapatkan informasi, sehingga mempermudah dalam mengambil keputusan. Informasi yang dibutuhkan haruslah berguna bagi yang memerlukan, sehingga kapanpun informasi tersebut di butuhkan dapat dengan cepat diberikan. Begitupun kesiapan perusahaan sangat dituntut dalam menghadapi era globalisasi yang makin ketat persaingannya.Setiap perusahaan memerlukan strategi dan perencanaan yang baik dalam menjalankan kegiatan usahanya agar tetap bertahan dalam menghadapi persaingan ketat dan tantangan dunia yang semakin sulit dan luas. Peranan manajemen dalam hal ini sangat menentukan dalam pengambilan keputusan untuk menyusun suatu strategi dan kebijakan perusahaan yang

Vol.2 No.1 - Februari 2016 mengarahkan perusahaan pada perencanaan yang mantap dengan di dukung oleh informasi yang akurat dan tepat. CV.Indonesia Elektronik merupakan sebuah perusahaan di bidang penjualan elektronik, dengan kegiatan utamanya pada penjualan kebutuhan elektonik rumah tangga.Didalam laporan penjualan barang pada perusahaan tersebut, terjadi permasalahan yang penulis temui. Hasil pengamatan di lapangan menunjukkan bahwa pengolahan data penjualan kurang dioptimalkan untuk dijadikan sebuah informasi yang berguna bagi perusahaan dan dengan pemanfaatan konsep data mining perusahaan dapat mengoptimalkan data-data penjualan untuk dijadikan sebuah informasi dan membantu perusahaan dalam pengambilan keputusan yang cepat dan tepat sehingga dapat membantu 
perusahaan untuk semakin berkembang kedepan

\section{PERMASALAHAN}

Berdasarkan Latar Belakang yang telah dijelaskan diatas, maka Penulis merumuskan beberapa masalah sebagai berikut :

1. Apakah sistem penjualan yang berjalan di CV.Indonesia Elektronik sudah dapat merpermudah admin dan pembeli melakukan transaksi ?

2. Apakah sistem yang ada CV.Indonesia Elektronik sudah dapat membantu meningkatkan jumlah penjualan?

3. Apakah data laporan penjualan dan stock barang pada CV. Indonesia Elektronik sudah akurat?

\section{LITERATUR REVIEW}

Banyak penelitian yang sebelumnya dilakukan mengenai Bisnis Online berbasis e-commers.. Beberapa Literature review tersebut adalah sebagai berikut :

1. Menurut Yulia Ningsih dalam Widuri Tugas Akhirnya yang berjudul "PERANCANGAN SISTEM INFORMASI PENJUALAN BAJU BATIK BERBASIS WEB (ONLINE SHOPPING) PADA CV. SELARAS BATIK"Perkembangan ilmu pengetahuan dan teknologi yang semakin pesat, dunia usaha ikut meramaikan perkembangan teknologi tersebut dengan menerapkan teknologi informasi yang dibantu dengan media komputer dalam melaksanakan kegiatan usahanya. Maka, untuk mendukung hal tersebut $\mathrm{CV}$. Selaras Batik yang merupakan salah satu yang bergerak di bidang perdagangan dan jasa selalu Inovatif dan kreatif untuk dapat memecahkan masalah-masalah, yaitu dengan menerapkan suatu sistempenjualan online yang bisa diakses dimanapun dan kapanpun. Dalam laporan

Vol.2 No.1 - Februari 2016 ini dijelaskan mengenai metode penelitian yang digunakan tinjauan lapangan, Pengamatan/obsevasi, wawancara, mengumpulkan dokumen, kepustakaan, analisa sistem menggunakan metode SWOT (Strengths Weaknesses Oportunities Threats), metode CSF (Critical Success Factor) dan beberapa elisitasi sampai final draft serta manfaat dari Penjualan Online itu sendiri, juga menggunakan metode analisa perancangan program yang di gambarkan dengan Unified Modelling Language (UML).Pada implementasinya ditampilkan prototype Penjualan Online, tools-tools yang digunakan, tampilan rancangan program, perangkat lunak, perangkat keras dan hak akses. Maka dapat disimpulkan bahwa kontribusi sistem Penjualan Online dapat memaksimalkan berbagai bentuk penjualan, serta dapat dijadikan media informasi yang valid bagi seluruh aktivitas CV. Selaras Batik dan masyarakat secara umum dimanapun dan kapanpun selain itu untuk memperoleh informasi baik, yang tentunya mempermudah dalam penjualan barang.[7]

2. Menurut jurnal Aris dan rekan, yang berjudul "DESAIN APLIKASI SISTEM INFORMASI PENJUALAN SECARA ONLINE PADA PT.ULTINET INDONESIA." Dalam bisnis modern ,kebutuhan akan teknologi informasi sangat mendukung untuk meningkatkan kinerja perusahaan.Dengan adanya kebutuhan informasi yang semakin meningkat,maka diperlukan suatu sistem yang lebih baik dan cepat.Dalam hal ini Business penjualan secara online yang merupakan tantangan maju dalam memenuhi teknologi informasi harus bisa menjawab permasalahan yang sedang terjadi pada PT.Ultinet Indonesia yang bergerak dalam bidang penjualan kopi di seluruh Indonesia, Dalam prosesnya penjualan yang dilakukan oleh PT.Ultinet 
Indonesia hanya dilakukan oleh marketing hanya menunjuk beberapa distributor yang mengambil barang dari perusahaan,dan tidak melakukan penjualan ke pedagang-pedagang kecil seperti agent maupun warung. Dengan sistem business penjualan secara online maka dibuatlah sebuah metode sistem yang akan menjawab dari permasalahan tugas marketing. Pengembagan dari aspek business yang sangat luas agar dapat memperloleh keuntungan yang besar dengan menekan biaya-biaya operasional yang besar,dan di butuhkan sebuah sistem penjualan produk yang memanfaatkan teknologi komputer berupa online.Penggunaan teknologi informasi untuk melakukan promosi dan pesanan produk sangatlah bermanfaat. Dengan membuat sebuah website dan dilakukan penjualan secara online dari mulai promosi produk dan terutama pemesan, dan dapat memudahkan para konsumen untuk memebeli produk , sekaligus dalam pengiriman. Penggunaaan sistem Business penjualan secara online untuk membantu dalam proses penjualan sangat tepat untuk menjawab tantangan bisnis yang begitu pesa yang banyak dengan berbasis Online.Hasil dari penerapan sistem Business penjualan secara online berupa website penjualan secara online sagat membantu para tugas marketing dalam mempromosikan produk dan mengelolah data para pemesan, dengan demikian laporan dari sistem ini juga dapat di pertanggung jawabkan karna semua data tersimpan dengan baik.pembuatan sistem ini di bantu dengan bahasa pemograman PHP dan data base SQL server yang akan mengelolah sietem penjualan online.[8]

3. Menurut Mahmudi dalam Jurnal dengan judul "Perancangan Sistem Informasi Penjualan Online Berbasis Web Pada Toko One Cell "Perkembangan Teknologi Informasi yang disertai perkembangan internet saling mendukung satu sama lain sehingga melahirkan konsep Teknologi Informasi berbasis internet yang perkembangannya semakin luas dan semakin banyak diterapkan dalam bisnis perusahaan di berbagai bidang demi tercapainya tujuan yang diinginkan oleh perusahaan. Teknologi internet sudah terbukti merupakan salah satu media informasi yang efektif dan efisien dalam penyebaran informasi yang dapat diakses oleh siapa saja, kapan saja dan dimana saja. Teknologi internet mempunyai efek yang sangat besar pada perdagangan atau bisnis. Hanya dari rumah atau ruang kantor, calon pembeli dapat melihat produk - produk pada layar komputer, mengakses informasinya, memesan dan membayar dengan pilihan yang tersedia. Calon pembeli dapat menghemat waktu dan biaya karena tidak perlu datang ke toko atau tempat transaksi sehingga dari tempat duduk mereka dapat mengambil keputusan dengan cepat. Transaksi secara online dapat menghubungkan antara penjual dan calon pembeli secara langsung tanpa dibatasi oleh suatu ruang dan waktu. Itu berarti transaksi penjualan secara online mempunyai calon pembeli yang potensial dari seluruh dunia. Sistem penjualan yang selama ini digunakan oleh Toko One Cell adalah dengan cara kerjasama dengan counter counter handphone untuk memasarkan handphone. Sistem penjualan dengan cara ini membutuhkan waktu yang lama dalam proses penjualan handphone tersebut, maka sistem ini dinilai kurang efektif dan efesien. Jika hanya mengandalkan sistem penjualan dengan cara tersebut maka pendapatan perusahaan tidak mengalami peningkatan yang signifikan. Selain itu perkembangan perusahaan terasa dinilai agak lambat. Oleh karena itu dirancang suatu sistem penjualan secara online dengan menggunakan media web atau internet dengan tujuan untuk meminimalkan waktu proses penjualan dengan tujuan

Vol.2 No.1 - Februari 2016 
dapat meningkatkan volume penjualan sehingga pendapatan perusahaan dapat meningkat.

\section{Pembahasan}

\section{Pengertian E-Commerce}

$\begin{array}{lcc}\text { Electronic } & \text { Commerce } & \text { (Perniagaan } \\ \text { Elektronik), } & \text { sebagai } & \text { bagian dari } \\ \text { Electronic } & \text { Business } & \text { (bisnis yang } \\ \text { dilakukan } & \text { dengan } & \text { menggunakan } \\ \text { electronic transmission), oleh para ahli } \\ \text { dan pelaku bisnis dicoba dirumuskan } \\ \text { definisinya. }\end{array}$

Secara umum e-commerce dapat didefinisikan sebagai segala bentuk transaksi perdagangan/perniagaan barang atau jasa (trade of goods and service) dengan menggunakan media elektronik. Jelas, selain dari yang telah disebutkan di atas, bahwa kegiatan perniagaan tersebut merupakan bagian dari kegiatan bisnis. Kesimpulannya, "e-commerce is a part of e-business".[1]

\section{Konsep E-Commerce}

konsep e-commerce terdiri dari :

Konsep Dasar Informasi yang berbasis dari teknologi informasi dan komunikasi untuk perdagangan dalam penggunaan internet.Penggunaan internet ini digunakan sebagai media informasi dalam melakukan transakasi berupa produk dan jasa.[2]

\section{Analisis Sistem}

sebagai penguraian dari suatu sistem informasi menjadi beberapa bagian kecil yang dimaksudkan untuk mengidentifikasikan kesalahan, kesempatan, hambatan,dan kebutuhan yang diharapkan sehingga dapat diusulkan pengembangan dari sistem informasi tersebut.[6]

\section{Perancangan Sistem}

Setelah tahap analisis sistem, maka diketahui kelemahan-kelemahan sistem tersebut. Sehingga dalam tahap ini dibuat persiapan dan perancangan rinci terhadap sistem informasi yang akan dibangun.[6]

\section{Mekanisme E-Commerce}

Pada mekanisme e-commerce ini, dimana pembeli yang hendak memilih belanjaan yang akan dibeli bisa menggunakan "shopping cart" untuk melakukan transaksi terhadap barang-barang yang telah dipilih dan akan dibayar.Shopping cart' biasanya berupa formulir dalam web, dan dibuat dengan kombinasi CGI, database, dan HTML.Setelah pembeli mengadakan transaksi, retailer akan mengirimkan barang yang dipesan melalui jasa pos langsung ke rumah pembeli. Beberapa cybershop menyediakan fasilitas bagi pembeli untuk mengecek status barang yang telah dikirim melalui internet.[2]

\section{Software untuk Pembuatan E- Commerce}

Dalam pembuatan toko online/ecommerce membutuhkan software atau aplikasi tertentu untuk mengatur inventarisasi barang dan transaksi penjualan.[3]

\section{Alternatif Pembayaran untuk E- commerce}

Untuk transaksi pembayaran, ecommerce memeiliki banyak alternatif. Caranya dengan mendaftar sebagai customer pada web tersebut. bagi customer yang memiliki kartu kredit dapat menggunakan kartu tersebut. Atau bisa juga menggunakan paypal, transfer bangking, ataupun cash delivery.

\section{Keamanan E-commerce}

Dalam prakteknya, berbelanja di web memerlukan koneksi ke internet dan browser yang mendukung transaksi elektronik yang aman, seperti Microsoft Internet Explorer dan Netscape Navigator. Standar enkripsi yang digunakan dalam e-commerce pada saat

Vol.2 No.1 - Februari 2016 
ini adalah SET (Secure Electronic Transaction). Selain digunakan untuk pembayaran dengan credit card, SET juga digunakan untuk pembayaran dengan smartcard. Dengan menggunakan SET, kerahasiaan informasi customer (berupa nama dan nomor kartunya) bisa dijaga. SET juga bisa menjaga autotentifikasi atau identitas penjual dan customer, sehingga tidak bisa disalahgunakan oleh sembarang orang.[3]

\section{Contoh E-Commerce \\ Belanja Online}

Membeli dan menjual barang di Internet adalah salah satu contoh paling populer dari e-commerce. Penjual membuat etalase produk di internet layaknya outlet ritel. Pembeli dapat mencari dan membeli produk dengan klik mouse. Contoh populer untuk tempat belanja secara online adalah Amazon.com.Pembayaran Elektronik.Lelang online Situs lelang online terkenal adalah eBay. [5]

\section{Tiket online}

Tiket pesawat terbang, tiket film, tiket kereta api, tiket pertunjukan musik, tiket pertandingan olahraga, tiket konser musik, dan hampir semua jenis tiket dapat dipesan secara online. Membeli tiket secara online menjadikan kita tidak harus capek mengantri di depan loket penjualan tiket.[2]

\section{enis E-commerce}

E-commerce dapat diklasifikasikan berdasarkan jenis pengguna dalam transaksi:

a.Bisnis ke Bisnis (B2B)

Transaksi B2B e-commerce adalah sebuah transaksi yang melibatkan dua pihak yang sama-sama organisasi atau pelaku bisnis seperti, produsen, pedagang, pengecer dan sejenisnya.

b.Business ke Konsumen (B2C)
Transaksi antara penjual, produsen dengan konsumen pemakai produk.

c.Konsumen untuk Konsumen (C2C)

Agak susah mengartikan $\mathrm{C} 2 \mathrm{C}$ tapi beberapa transaksi awal dalam sistem ekonomi global melibatkan barter - jenis transaksi C2C. Situs lelang adalah contoh yang baik dari $\mathrm{C} 2 \mathrm{C}$ e-commerce.[5]

\section{Manfaat E-Commerce}

Cara efisien dalam bertransaksi dikarenakan meniadakan batasan wilayah geografis dan batasan waktu, artinya transaksi ecommerce bisa dilakukan kapan saja dan dimana saja selama dapat terhubung secara online. Dalam proses ini, e-commerce biasanya mempermudah operasional dan menurunkan biaya.[5]

\section{Metode Perancangan Framework e- Commerce}

Klasifikasi EC menurut Pola Interaksi/Transaksi yaitu B2B dan B2C Business-to-business-to-consumer

(B2B2C) : model EC dimana suatu perusahaan menjual produk atau jasa kepada perusahaan lain yang memiliki konsumennya sendiri.[5]

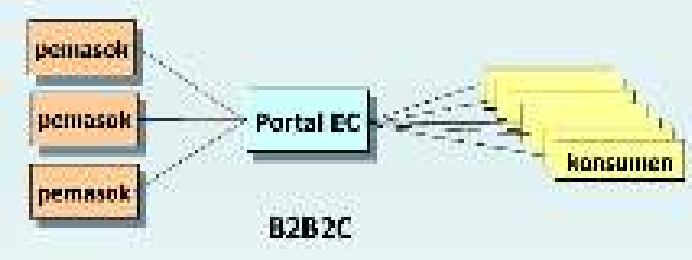

Metod didalam perancangan proses pada pengembangan perangkat lunak menggunakan UML Unified Modelling Language (UML) singkatan dari Unified Modelling Language yang berarti bahasa pemodelan standar,berarti UML memiliki sintaks dan semantik. Ketika kita membuat model menggunakan konsep UML ada aturan - aturan yang harus diikuti. [4] 


\section{Implementasi}

\section{a.Rancangan Sistem Yang Diusulkan Pada Use Case Diagram Customer}

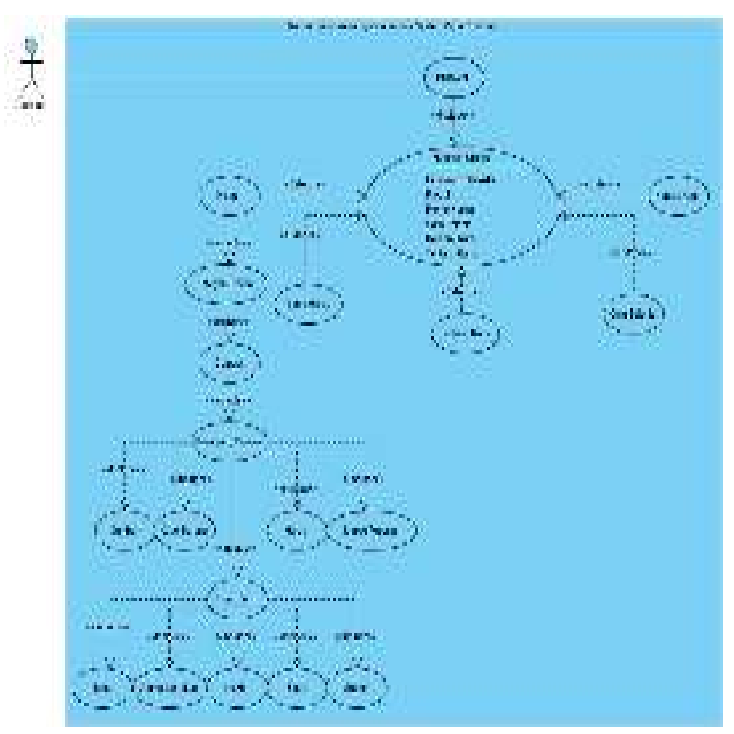

Gambar 1. Use Case Diagram Pada Customer

Berdasarkan gambar 1 diatas, rancangan use case diagram pada customer terdapat :Satu buah sistem yang merupakan rancangan usulan proses sistem pada customer.

1. Satu buah aktor, yaitu customer yang dapat melakukan kegiatan yaitu proses browsing, melihat halaman utama dan melakukan pemesanan.

2. Terdapat 20 use case yang dapat dilakukan yaitu, customer melakukan browser untuk dapat masuk ke website CV.Indonesia Elektronik. Halaman utama yang terdiri dari 5 menu yaitu, produk yang menampilkan menu kategori produk didalamnya dan terdapat fasilitas menu gambar produk. Pada fasilitas gambar didalamnya terdapat menu keranjang belanja yang menampilkan fasilitas gambar, kode barang, harga dan jumlah pesanan. Pada keranjang belanja juga terdapat menu insert form untuk customer mengisi biodata yang terdiri dari nama, alamat lengkap, no hp, email dan submit. Selain itu terdapat juga menu promo harga, menu kontak kami,menu tentang kami, dan menu cara berbelanja.

\section{b.Rancangan Sistem Yang Diusulkan Pada Use Case Diagram Admin}

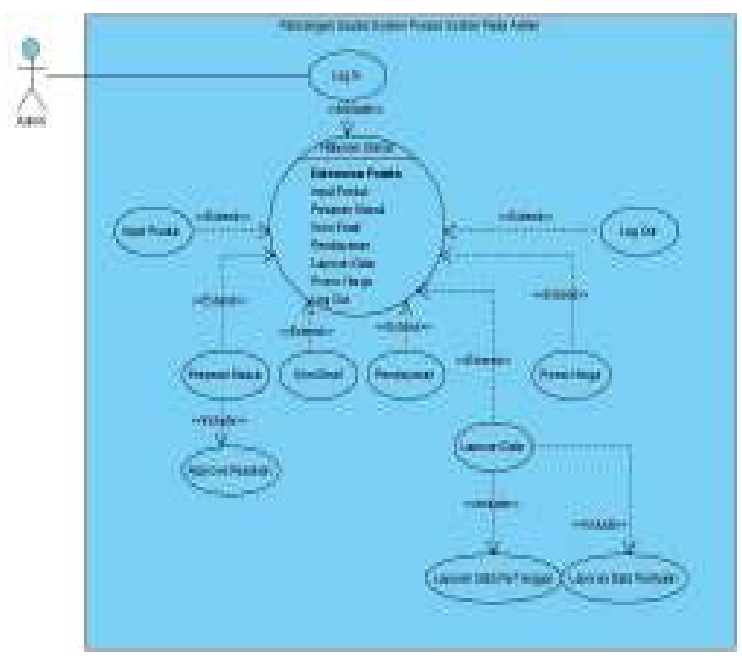

Gambar 2. Use Case Diagram Pada Admin

Berdasarkan gambar 2 diatas, rancangan use case diagram pada admin terdapat :

1. Satu buah sistem yang merupakan rancangan usulan proses sistem pada admin.

2. Satu buah aktor, yaitu admin yang dapat melakukan kegiatan mengapprove pesanan customer dan membuat laporan penjualan.

3. Terdapat 12 use case yang dapat dilakukan yaitu, admin membutuhkan password untuk log in, menu halaman utama terdiri dari enam menu yaitu menu produk yang didalamnya terdapat menu kategori produk, menu cek pesanan masuk yang didalamnya terdapat fasilitas approve pesanan customer, admin input pada menu pembayaran customer, menu laporan penjualan yang terdiri dari laporan penjualan pertanggal, laporan penjualan perbulan. Terdapat juga 
menu promo harga, cara berbelanja,pembayaran,kirim email, kontak kami dan menu log out.

\section{c.Rancangan Sistem Yang Diusulkan Pada Sequence Diagram Pada} Customer

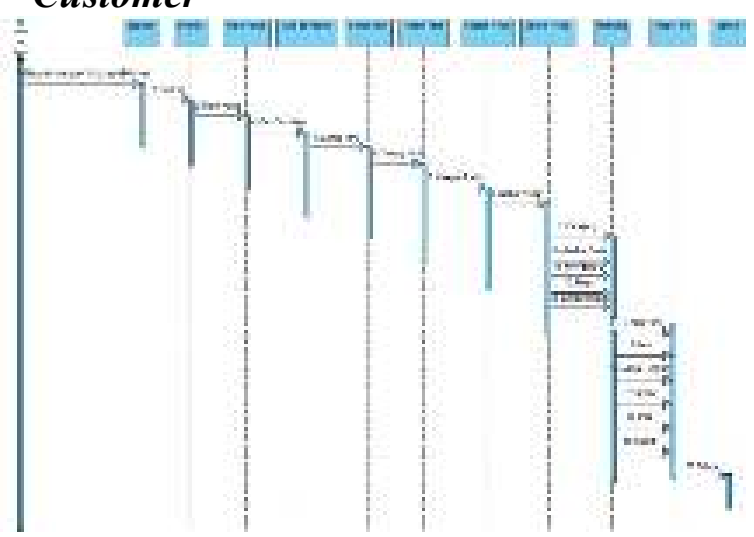

Gambar 3. Sequence Diagram Pada Customer

Keterangan :

1.Terdapat satu aktor yaitu customer.

2.Terdapat sebelas lifelines yang dilakukan oleh customer dalam melakukan kegiatan antara lain customer melakukan browsing untuk dapat masuk ke dalam halaman utama CV.Indonesia Elektronik. Customer juga dapat surfing ke dalam menu halaman utama diantaranya promo harga,, cara berbelanja, kontak kami,kategori produk Dan untuk melakukan pemesanan customer dapat masuk ke menu produk kemudian pilih menu kategori produk, gambar, keranjang belanja, insert form. Setelah menyelesaikan pengisian biodata lengkap pada insert form maka customer telah selesai dalam pemesanan produk.

3. Terdapat dua puluh message yaitu, customer masuk ke dalam situs CV.Indonesia Elektronik melalui browser, menu halaman utama, promo harga, cara berbelanja, kontak kami, produk, menu kategori produk, gambar, keranjang belanja, gambar, kode Vol.2 No.1 - Februari 2016 baranng, harga, jumlah pesanan, insert form, nama, alamat lengkap, no hp, email, submit dan selesai.

\section{d.Rancangan Sistem Yang Diusulkan Pada Sequence Diagram Pada Admin}

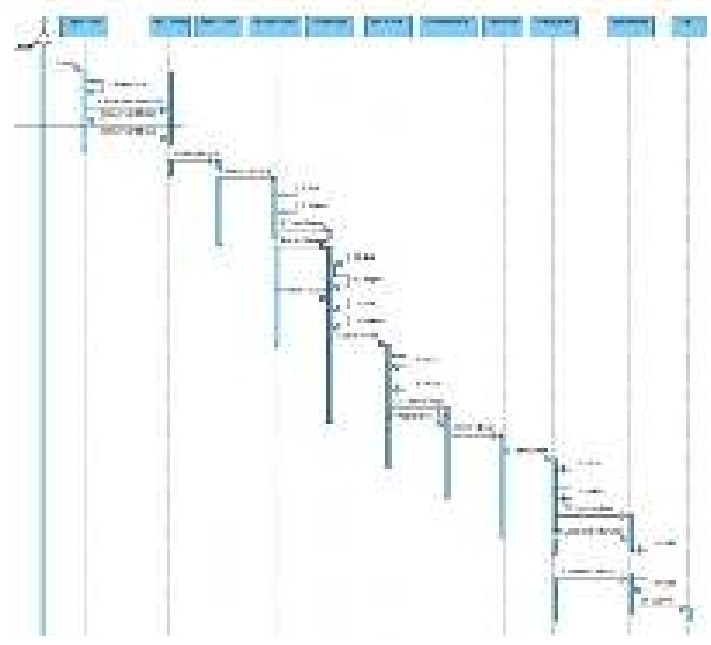

Gambar 4. Sequence Diagram Pada Admin

Pada gambar 4 Sequence Diagram Pada Admin terdiri dari :

1.Terdapat satu aktor yaitu admin.

2.Terdapat sebelas lifeline yaitu $\log$ in admin, menu admin, input produk, menu kategori produk, promo harga, pesanan masuk, kirim email, pembayaran, laporan data dan yang terakhir adalah $\log$ out.

3.Terdapat satu loop combined fragment yang merupakan kegiatan perulangan pada saat $\log i$.

4.Terdapat tujuh belas message yang terdiri dari log in, konfirmasi password, password benar, menu produk, menu kategori produk, promo produk harga, promo mingguan, promo bulanan, cara berbelanja, kontak kami, pesanan masuk, approve pesanan, pembayaran customer, laporan data, laporan pertanggal, laporan perbulan, dan yang terakhir log out.

5.Terdapat empat belas self message yang terdiri dari autentifikasi password pada saat admin melakukan $\log$ in, password 
salah, fasilitas edit dan delete pada menu kategori produk, fasilitas edit dan hapus pada promo mingguan, fasilitas edit dan delete pada promo bulanan, fasilitas print pada menu approve pesanan, pada menu pembayaran terdapat fasilitas input dan hapus, fasilitas print pada menu laporan pertanggal, fasilitas print pada menu laporan perbulan.

\section{f.Rancangan Sistem Yang Diusulkan Pada Class Diagram}

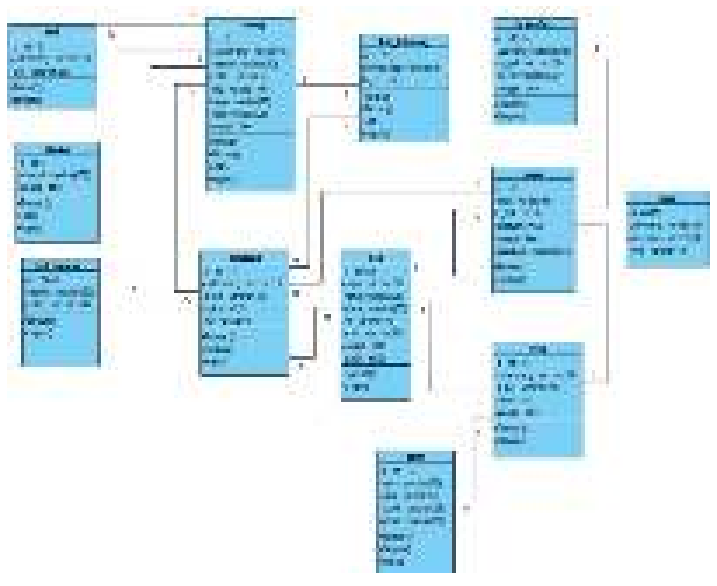

Gambar 5. Rancangan Class Diagram

Spesifikasi database merupakan desain basis data yang dianggap telah normal. Desain database menjelaskan media penyimpanan yang digunakan, isi yang disimpan.

\section{g.Tampilan Program}

\section{Tampilan Halaman Login Pada Admin}

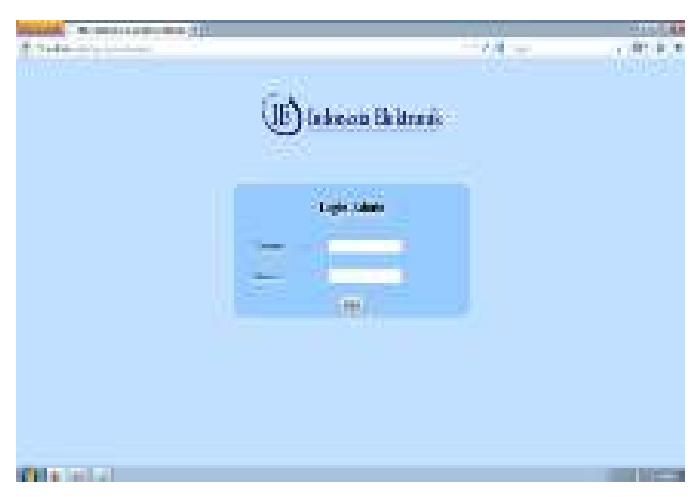

Vol.2 No.1 - Februari 2016
Gambar 6. Tampilan Halaman Login Pada Admin

Pada gambar 6 merupakan tampilan pertama admin untuk masuk kearea admin dimana harus memasukan user dan password.

\section{Tampilan Halaman Utama Pada Admin}

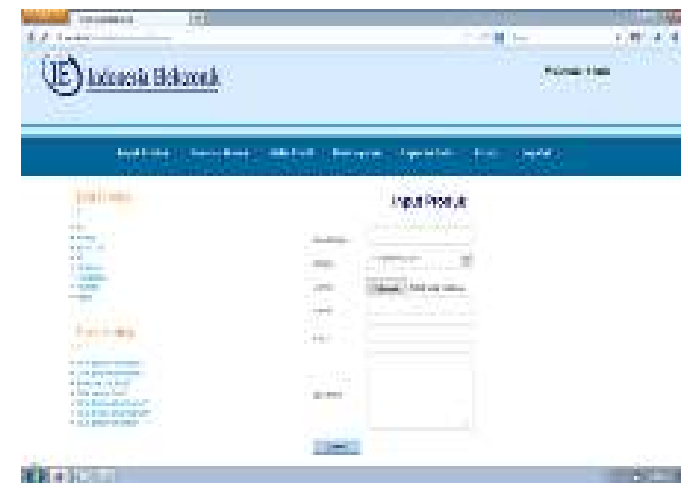

Gambar 7. Tampilan Halaman Utama Pada Admin

Pada gambar7 merupakan halaman admin untuk memproses semua menu transaksi.

Tampilan Halaman Pesanan Masuk Pada Admin

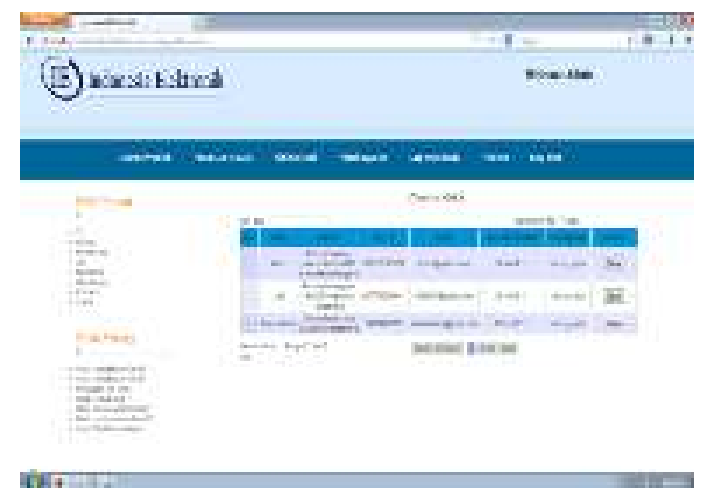

Gambar8. Tampilan Halaman Pesanan Masuk Pada Admin

Pada gambar 8 merupakan tampilan pesanan dari costumer yang sudah masuk ke menu admin untuk pesanan beberapa barang. 


\section{Tampilan Halaman Data Penjualan}

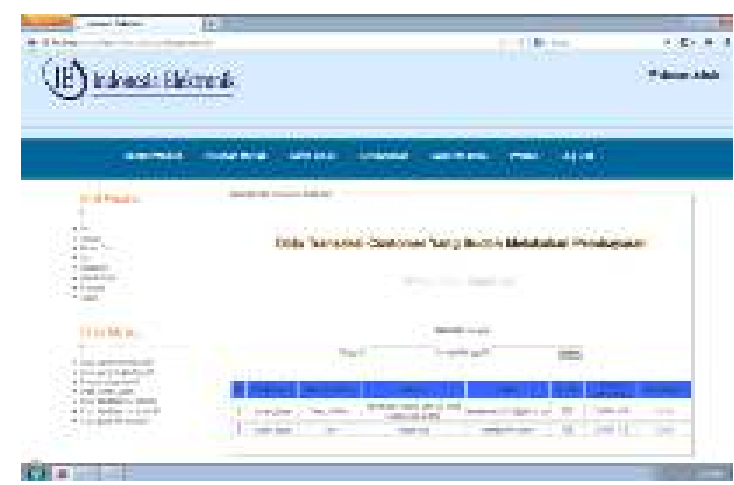

Gambar9. Tampilan Halaman Data Penjualan

Pada gambar 9 merupakan tampilan menu halaman data transaksi penjualan

\section{Tampilan Halaman Input Promo}

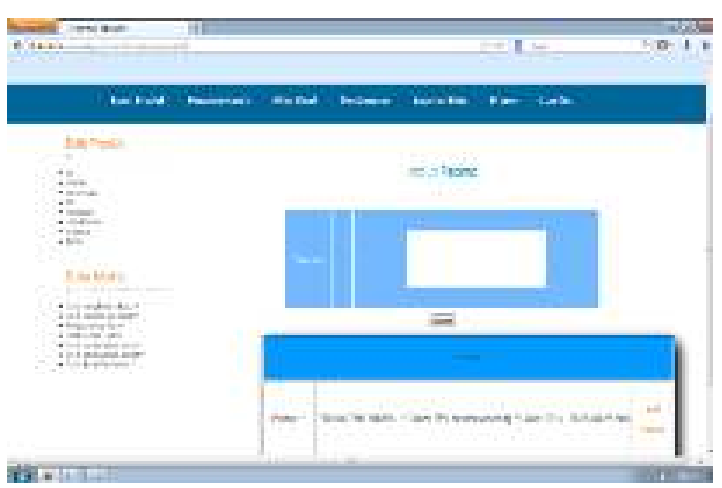

Gambar 10. Tampilan Halaman Input Promo

Pada gambar 10 merupakan menu halaman input promo yang dilakukan oleh admin untuk mempromosikan produk elektronik yang baru.

\section{Tampilan Halaman Pada Cutomers}

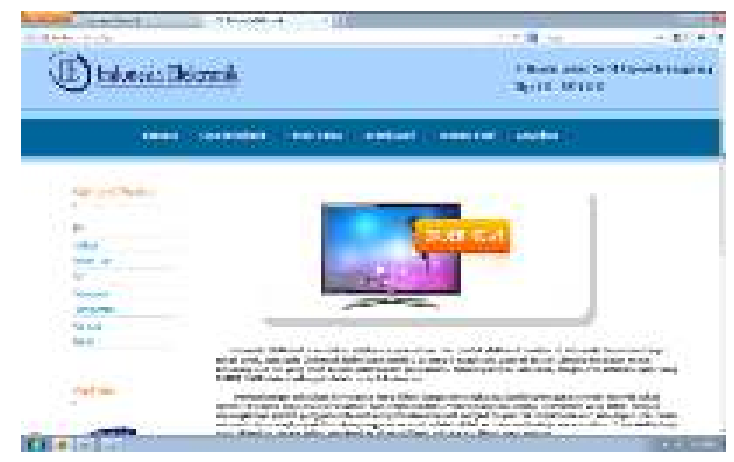

Vol.2 No.1 - Februari 2016
Gambar 11. Tampilan Halaman Utama Pada Customer

Pada gambar 11 merupakan tampilan utama customer pada saat buka web diman disajikan informasi produk .

\section{Tampilan Halaman Cara Berbelanja}

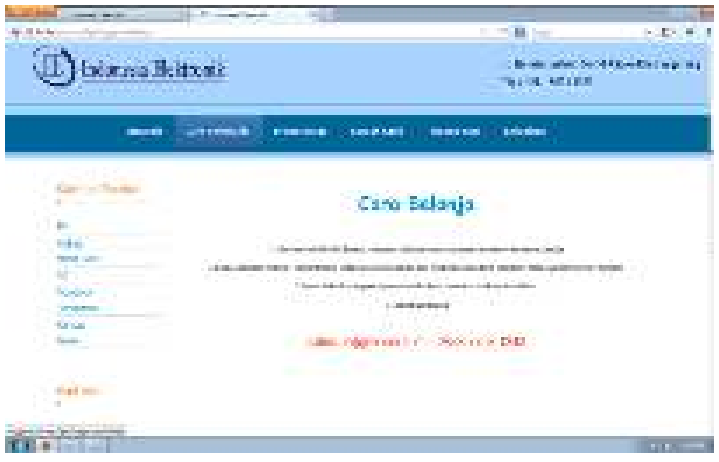

\section{Gambar 12. Tampilan Halaman Cara} Berbelanja Pada Customer

Pada gambar 12 menjelaskan cara belanja para customer untuk memelakukan transaksi pembelian barang .

\section{Tampilan Halaman Promo Harga Pada Customer}

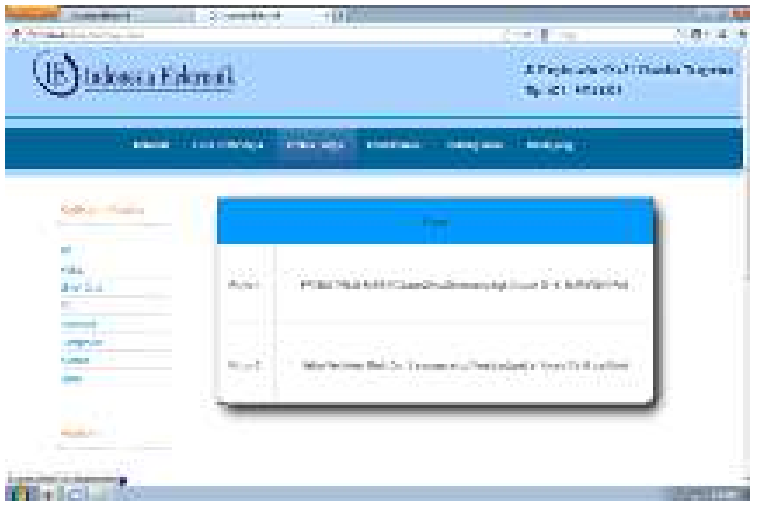

Gambar 13. Tampilan Halaman Promo Harga

Pada gambar 13 merupakan menu informasi promo harga barang yang sedang diskon. 


\section{Tampilan Halaman Tentang Kami}

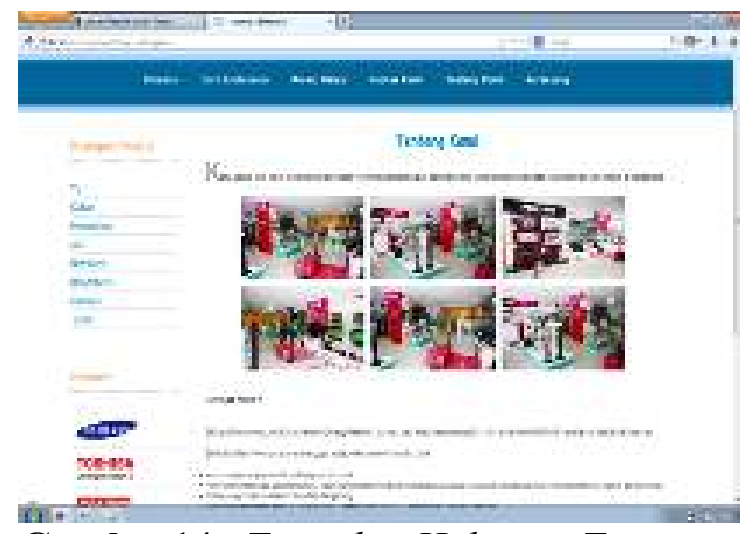

Gambar14 . Tampilan Halaman Tentang Kami

Pada gambar 14 menampilkan menu tentang informasi perusahaan

\section{Tampilan Halaman Keranjang Anda}

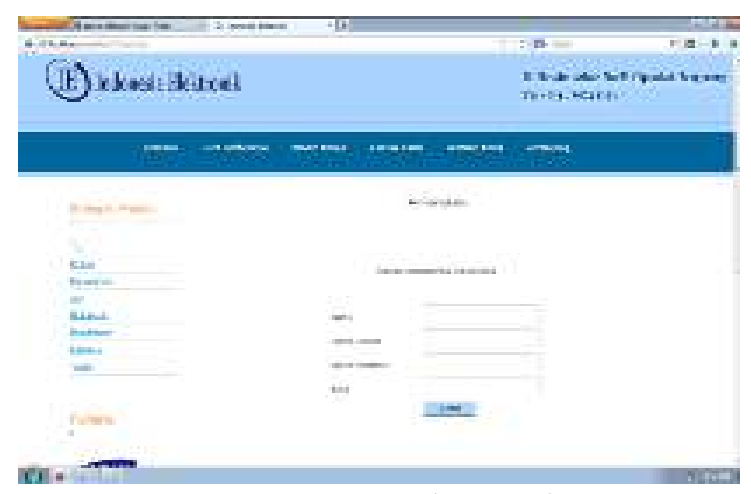

Gambar 15 .Tampilan Halaman Keranjang Anda

Pada gambar 15menampilkan halaman menu keranjang belanjaan customer yang sudah memesan barang yang akan masuk ke menu pesanan.

\section{Tampilan Halaman Kategori Produk Pada Customer}

Vol.2 No.1 - Februari 2016

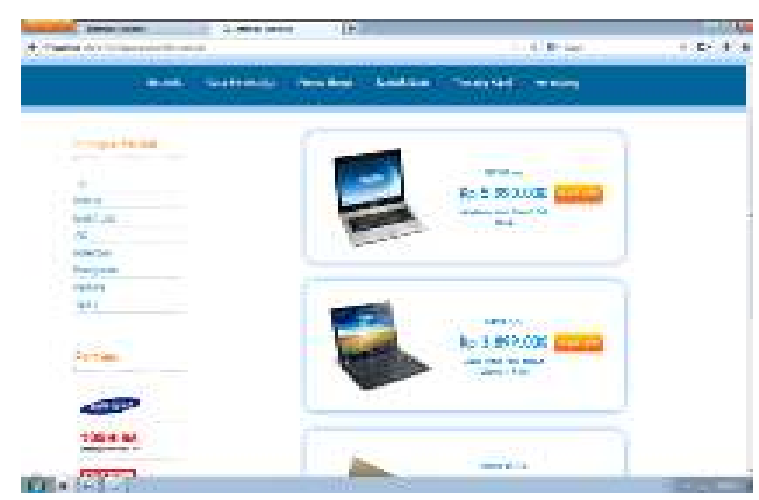

Gambar16.Tampilan Halaman Kategori Pada Customer

Pada gambar 16 menamnpilkan kategori produk barang yang dijual kepada customer.

\section{Kesimpulan}

Setelah mempelajari permasalahan yang dihadapi pada CV.Indonesia Elektronik mengenai proses penjualan serta juga solusi pemecahan yang ditawarkan, maka dapat ditarik beberapa kesimpulan sebagai berikut:

1. Sistem informasi penjualan yang berjalan di CV.Indonesia Elektronik telah menggunakan pencatatan secara komputerisasi dalam proses penjualan sehingga konsumen dapat melakukan pesanan barang kepada admin dengan mudah sesuai yang ada di website.

2. Sistem Informasi yang dihasilkan pada CV. Indonesia Elektronik sudah dapat meningkatkan penjualan produk barang elektornik setelah menerapkan sistem online ,d ikarnakan informasi yang di dapat oleh para konsumen sangan mudah hanya cukup memesan dan membayar secara online.

3. Data yang dihasilkan pada CV. Indonesia Elektronik saat ini sangat akurat dikarenakan teknologi yang digunakan pada perusahaan tersebut telah komputerisasi sehingga keakuratan data dalam pembuatan laporan dan membutuhkan waktu yang singkat dalam pengolahan data sehingga tingkat efisiensi yang 
diharapkan telah tercapai dan sudah adanya tempat penyimpanan data sehingga data yang ada dapat aman.Terutama laporan data stock barang dan laporan penjualan.

4. Dengan system E-Commerce penjualan barang kepada konsumen dapat mudah dilakukan tanpa banyak biaya promosi yang di keluarkan,terutama promosi dan pemesanan barang yang sudah teratasi dengan sistem online ini.

\section{Daftar Pustaka}

[1] Loudon, "Strategi E-Commerce Dalam Dunia Bisnis", Yudistira.Bandung, 2011

[2] Juanda. Panduan menjadi Entrepreneur secara ECommerce.Yudistira Jakarta,2014

[3] Mulyanto. Agus.. Sistem Informasi Konsep dan Aplikasinya. Yogyakarta: Pustaka Pelajar. 2009

[4] Nugroho. Adi.. Rekayasa Perangkat Lunak Menggunakan UML dan Java. Yogyakarta: Andi Offset. 2009
[5] Woro Widya . "Pemodelan Perancangan Sistem Penjualan". Grasindo, Jakarta. 2008.

[6] Kadir. Abdul.. Pengenalan Sistem Informasi. Yogyakarta: Andi. 2009

[7] Yulia Ningsih "PERANCANGAN SISTEM INFORMASI PENJUALAN BAJU BATIK BERBASIS WEB (ONLINE SHOPPING) PADA CV. SELARAS BATIK" Tangerang. Widuri TA, 2014

[8] Aris dkk," DESAIN APLIKASI SISTEM INFORMASI PENJUALAN SECARA ONLINE PADA PT.ULTINET INDONESIA." Yogyakatra,SEMNASTEKNOMED IA .2016

[9] Mahmudi "Perancangan Sistem Informasi Penjualan Online Berbasis Web Pada Toko One Cell", TEKNOKRAT.BANDAR 